\title{
Animal Performance with and without Supplements in Mombaça Guinea Grass Pastures during Dry Season
}

\author{
Itânia Maria Medeiros de Araújo ${ }^{1}$, Gelson dos Santos Difante ${ }^{1}$, Valéria Pacheco Batista Euclides ${ }^{2}$, \\ Denise Baptaglin Montagner ${ }^{2} \&$ Rodrigo da Costa Gomes ${ }^{2}$ \\ ${ }^{1}$ Animal Science Post-Graduation Program, Federal University of Rio Grande do Norte, Macaiba, RN, Brazil \\ ${ }^{2}$ Embrapa Beef Cattle, Campo Grande, MS, Brazil \\ Correspondence: Gelson dos Santos Difante, Animal Science Post-Graduation Program, Federal University of \\ Rio Grande do Norte, RN 160, Km 03, Distrito de Jundiaí, Macaíba/RN, Caixa Postal 07, CEP: 59280-000, \\ Brazil. Tel: 55-84-3342-4821. E-mail: gdifante@hotmail.com
}

Received: March 17, 2017

Accepted: May 26, 2017 Online Published: June 15, 2017

doi:10.5539/jas.v9n7p145

URL: https://doi.org/10.5539/jas.v9n7p145

\begin{abstract}
The objectives were to: 1) evaluate the potential of the animal performance on Panicum maximum cv. Mombaça (mombaça guinea grass) pasture during dry season, and 2) determine the effects of protein or protein-energy supplementation on liveweight gain of steers grazing guinea grass pasture. A complete randomized block design was employed with three treatments and three replicates. Treatments included non-supplemented animals (NS) and animals supplemented with protein (PS) or protein-energy (PES), provided at $0.15 \%$ or $0.6 \%$ of body weight for 115 days, during dry period. We used 36 weaned calves from initial bodyweigh (LW) of $192 \mathrm{~kg}( \pm 5 \mathrm{~kg})$ on nine plots of mombaça guinea grass (1.25 ha each). Each month, animals were weighed and pastures sampled to estimate forage characteristics. The average daily gain $(\mathrm{ADG})$ was greater $(\mathrm{P}=0.0001)$ for cattle fed supplement than for cattle fed no supplement $\left(250 \mathrm{~g} \mathrm{steer}^{-1}\right)$, and greater for protein-energy supplement $\left(770 \mathrm{~g} \mathrm{steer}^{-1}\right)$ than for protein supplement $\left(460 \mathrm{~g} \mathrm{steer}^{-1}\right)$. Mombaça guinea grass pastures with $45 \mathrm{~cm}$ height at the end of the wet season have enough forage mass for maintenance throughout the dry season about $1.4 \mathrm{AU} \mathrm{ha}^{-1}(\mathrm{AU}=450 \mathrm{~kg}$ $\mathrm{BW}$ ), and reasonable nutritive value (average of $8,1 \%$ of crude protein and $55,3 \%$ of in vitro organic matter digestibility) to provide small gains. Considering the nutritive value of Mombaça guinea grass during the dry period, protein and energy supplementation is required for weaned calves to optimize their performance.
\end{abstract}

Keywords: forage allowance, nutritive value, protein supplement, protein-energy supplement

\section{Introduction}

In Brazil, cultivated grasslands are mainly comprised with species and cultivars of Brachiaria and Panicum. Beef and dairy cattle production systems are based mostly on pasture production, which is main source of animal feed. About $90 \%$ of the nutrients required by the ruminants are obtained directly through grazing. However, seasonality of forage production, a common feature of tropical pastures, is one of the bottlenecks for pasture-raised cattle production. In this context, Euclides et al. (2008) observed that approximately $80 \%$ of annual herbage accumulation in Panicum maximum cv. Mombaça occurs in the wet months (September-April) and the remains $20 \%$ occurring from May to September. This seasonality was also characterized by marked reductions in the percentages of crude protein and in vitro organic matter digestibility, and consequently decreased in animal daily gain. Thus, eliminating or reducing the seasonality of animal performance has been a challenge (Euclides et al., 2012).

To prevent degradation of pastures reduction of the stocking rate in dry season is of primary importance. In this context, Santana et al. (2013) found that only adjusting the stocking rate as a function of forage mass at the beginning of the dry season made it possible to obtain a daily gain of $530 \mathrm{~g}$ per calf ( $1 / 2$ Angus- $1 / 2$ Nellore; Braford 1/2-1/4 Angus-Nellore; and 1/4-1/2 Brahman-1/4 Angus-1/4 Nellore) in tanzania guinea grass pastures.

On the other hand, protein and energy supplemental feeding during this critical period are an effective way to improve the nutritional status of the animals, and consequently animal performance (Silva et al., 2009; Santana et al., 2013; Morais et al., 2014). Euclides and Medeiros (2005) built a database from results published in Brazil that used protein and energy supplemental feending during the dry season. The analysis of dietary 
supplementation effect on live weight gain and on feed conversion led the authors to suggest that modest supplementation contributed to the economic improvement of production systems, not only by lowering costs, but also by increasing the efficiency of inputs, particularly by maximizing the use of forage pasture. In this context, Euclides et al. (2009) observed that higher weight gains, resulting from higher levels of supplementation during the dry season, proved to be uneconomical.

Our objective were to: 1) evaluate the potential of animal performance on Panicum maximum cv. Mombaça pasture during dry season, and 2) determine the effects of protein or protein-energy supplementation on liveweight gain of steers grazing guinea grass pasture.

\section{Materials and Methods}

\subsection{Experimental Site, Treatments and Design}

The experiment was conducted at Embrapa Beef Cattle in Campo Grande, Brazil $\left(20^{\circ} 27^{\prime} \mathrm{S}\right.$ and $54^{\circ} 37^{\prime} \mathrm{W}$, at 530 $\mathrm{m}$ above sea level), from May to October 2013.

The climate, according to the Köppen climate classification, is type AW, rainy tropical savanna, with a defined dry season from May to September. During the experimental period, rainfall, absolute minimum, average, and absolute maximum temperatures were recorded (Figure 1A). On Figure 1A we presented the historical 30-year rainfall. To calculate the water balance, we used the mean temperature and the accumulated monthly rainfall. The soil water storage capacity was $75 \mathrm{~mm}$ (Figure 1B).
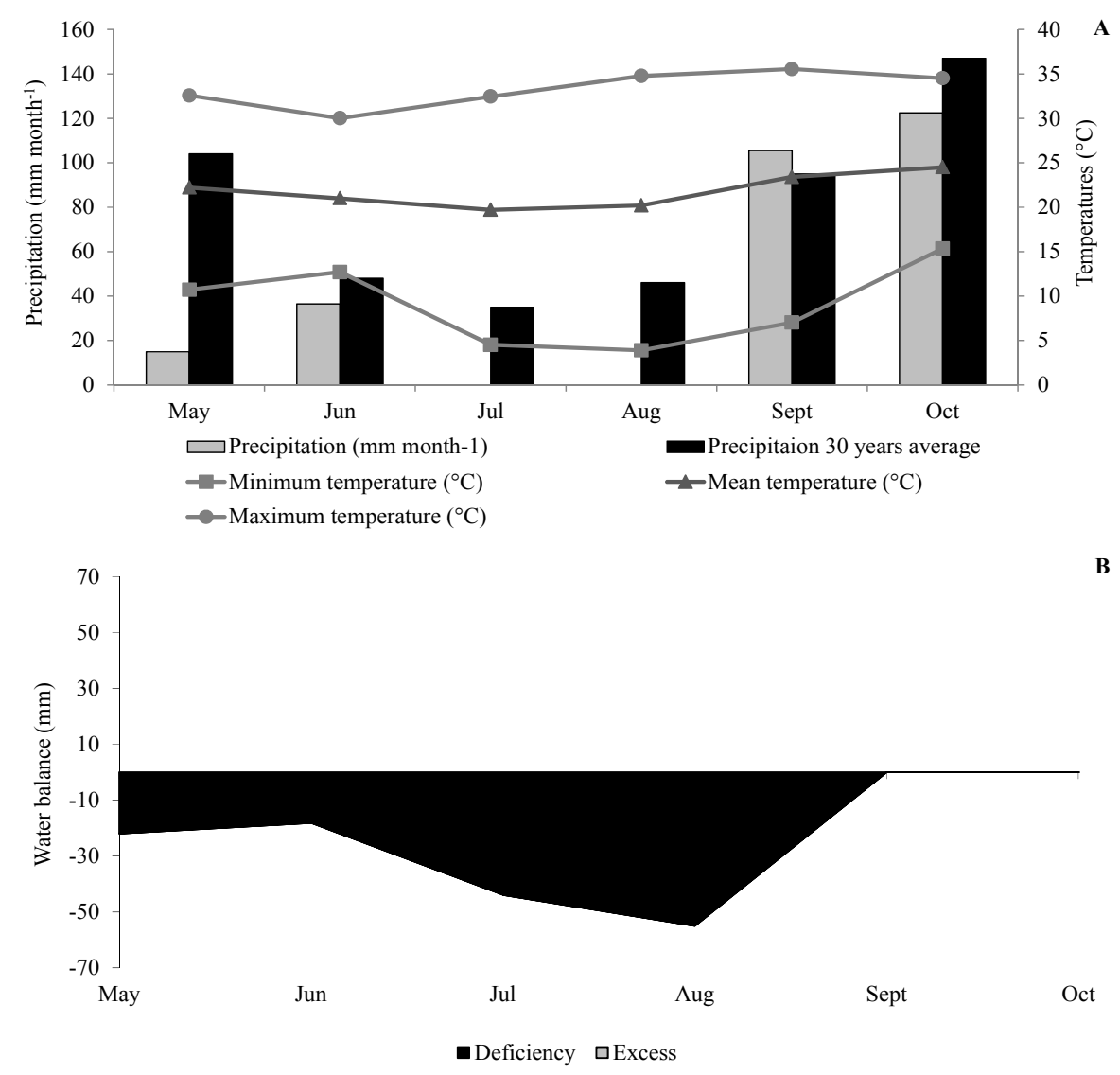

Figure 1. Monthly rainfall and absolute maximum, mean, and absolute minimum temperatures from May to October 2013, and historical 30-year average rainfall (A), and monthly water balance extract from May to October 2013, for a soil water holding capacity of $75 \mathrm{~mm}$ (B)

In November 2012, Panicum maximum cv. Mombaça (guinea grass mombaça) pastures were fertilised with 90 $\mathrm{kg} \mathrm{ha}^{-1}$ of $\mathrm{P}_{2} \mathrm{O}_{5}, 90 \mathrm{~kg} \mathrm{ha}^{-1}$ of $\mathrm{K}_{2} \mathrm{O}$ and $150 \mathrm{~kg} \mathrm{ha}^{-1}$ of $\mathrm{N}$, in the form of urea, divided among three application times, namely, December 2012, January 2013, and February 2013. During the previous rainy season (from 
October to April), the pastures were managed under rotational stocking with a post-grazing height of $45 \mathrm{~cm}$. No irrigation was used during the experimental period.

The experimental area was 13.5 ha, divided into nine paddocks of 1.5 ha each. The grazing method used was continuous stocking with a fixed stocking rate, using thirty six weaned Senepol-Caracu F1 calves with approximately 8 months old, and average initial bodyweight of $192 \pm 5 \mathrm{~kg}$. Four calves were placed in each paddock (experimental units); the differences in allocation bodyweight (BW) across treatments were not significant at the beginning of the experiment. Each group of animal remained on the same paddock and received the same treatment throughout the experimental period.

A completely randomized blocks experimental design was used, with three treatments and three replicates. Three supplement treatments were randomly allotted to pastures (3 paddocks/treatment), consisting of: 1) non-supplemented animals; 2) protein supplement at $0.16 \% \mathrm{BW}$; or 3) protein-energy supplement at $0.6 \% \mathrm{BW}$. The supplement offered was adjusted for the targeted rate on 28-d intervals four times during the experimental period. For that purpose we used the average bodyweight of the group of four animals

We used the "Embrapa Invernada" program to calculate the composition of the supplements (Barioni, 2011). Supplements were formulated to allow the diet (forage plus supplement) to reach $13 \%$ crude protein, to meet NRC (1996) recommended mineral requirements and to provide different energy intake between treatments. The proportions and chemical composition of the ingredients are listed in Table 1.

Table 1. Percentage of ingredients, chemical composition of the supplements, daily supplement intake and supplement cost

\begin{tabular}{lll}
\hline \multirow{2}{*}{ Component } & \multicolumn{2}{c}{ Supplements } \\
\cline { 2 - 3 } & Protein & Protein-energy \\
\hline Soybean meal 45\% & 28.0 & 31.8 \\
Urea & 8.0 & 1.3 \\
Corn grain ground & 52.0 & 58.2 \\
Mineral salt & 7.0 & 8.7 \\
Sodium chloride & 5.0 & - \\
\hline Food composition $(\%)^{2}$ & & \\
Dry matter & 92.2 & 24.5 \\
Crude protein & 43.6 & 8.6 \\
Neutral detergent fiber & 7.2 & 3.1 \\
Ether extract & 2.4 & 75.9 \\
TDN $(\%)$ & 68.4 & 1.550 \\
\hdashline Daily supplement intake $(\mathrm{g}$ animal & \\
Supplement cost $\left(\mathrm{US} \mathrm{kg}^{-1}\right)^{3}$ & 350 & 0.27 \\
\hline
\end{tabular}

Note. ${ }^{1}$ Mineral composition: sodium chloride, 48.75\%; flowers of sulfur, 7.36; dicalcium phosphate, 39.26\%; potassium iodide, $0.015 \%$; sodium selenite, $0.008 \%$; sulfate cobalt , $0.014 \%$; sulfate copper, $0.69 \%$; zinc sulfate, $3.89 \%$.

${ }^{2}$ The chemical composition of the supplements was obtained from the EMBRAPA Invernada program.

${ }^{3}$ Current prices in May 2017.

The animals in each plot had at their disposal two troughs, each of them measuring $1.0 \times 0.5 \times 0.5 \mathrm{~m}$, representing sufficient space for all animals at same time, in order to avoid any competition for supplement. Daily at 8:00 am the supplements were provided, for 115 days (from 06.18.2013 to 10.08.2013). Steers usually consumed their allotment within 10 to 15 minutes, after this time there were no refusals in the troughs. The supplement adaptation period consisted of $15 \mathrm{~d}$ (from 06.02.2013 to 06.17.2013). A mineral salt was provided ad libitum for non-supplement group of animals.

During the experimental period, the animals were treated ectopically with an insecticides needed to control ticks and horn fly. 


\subsection{Measures}

\subsubsection{Sward Height, Herbage Mass, Morphological Composition and Nutritive Value}

The sward height was measured every 28 days with a 1-meter ruler, graduated in centimeters, at 40 random points in each plot. The height of each point was the mean height of the canopy around the ruler. At the same time, nine samples of $1 \mathrm{~m}^{2}$ per plot were cut at ground level. Each sample was divided into two subsamples. One was dried and weighed to estimate the herbage mass; the other was separated into leaf (leaf blade), stem (stem + sheath), and dead material, then dried and weighed to estimate the morphological components.

Leaf and stem samples were ground to $1 \mathrm{~mm}$ and analyzed for percentages of crude protein, in vitro organic matter digestibility, neutral detergent fiber and acid detergent lignin, using the Near Infrared Reflectance Spectrophotometry (NIRS) system, as described by Marten et al. (1989).

The daily forage allowance (Allen et al., 2011) was calculated by dividing the forage mass by the total bodyweight of animals per paddock, and divided by the number of days between samplings.

\subsubsection{Forage Accumulation}

To estimate forage accumulation, an area of 0.25 ha was excluded from grazing in all paddocks ( $1.5 \mathrm{ha}$ ), so the grazing area per paddock was reduced to $1.25 \mathrm{ha}$. After 28 days that plot was opened for grazing and a new area of 0.25 ha was excluded from grazing and so on every $28-\mathrm{d}$. Those areas were sampled every time they were excluded and opened for grazing. Nine samples of $1 \mathrm{~m}^{2}$ per plot were cut at ground level and processed as described above. Forage accumulation rate was calculated as the difference between the forage mass when the plot was opened and forage mass when it was excluded from grazing, considering only the green portion (leaves and stems), dividing by the number of days between samplings.

\subsubsection{Animal Liveweight Gain}

All animals were weighed shrunk at 28-d intervals. A 16-hour pre-weighing fasting period was imposed to minimize gut-fill effects on bodyweight measurements (i.e. fasted from both water and feed). The average daily gain was calculated as the increase in bodyweight of the steers divided by the number of days between weighing.

The bodyweight gain per area (1.25 ha) was calculated by multiplying the average daily gain by the number of steers retained per paddock and the number of days of experimental period (112 days).

\subsection{Statistical Analysis}

Data were statistically analyzed by the least square method using the GLM procedure available in SAS Institute (2013). We used the mathematical model containing the random effect of block and the fixed effects of supplement, month, and their interactions. The month was included as a continuous variable in all analyses. Based on previous analyses, the higher order polynomial was selected for each dependent variable. In the event that there was no adjustment of a linear equation, the month was regarded as class variable, and we used the same model and compared the means using Tukey's test at 5\% probability.

\section{Results and Discussions}

\subsection{Pasture Characteristics}

When sward characteristics were compared among supplement treatments (Table 2) all paddocks presented similar forage accumulation rate, hence they were similar for sward height, forage mass and daily forage allowance. The percentages of leaf (LP), stem (SP), and dead material (DP) were also equal, resulting in sward structure similar among pastures. Likewise, the variables associated to the nutritive values in the leaves and stems, expressed as crude protein (CP), in vitro organic matter digestibility (IVOMD), neutral detergent fiber (NDF), and acid detergent lignin (ADL), were similar. As there was no supplement $x$ month interaction for those variables (Table 2), it could be concluded that the pastures were similar throughout the experimental period for all variables associated to the pasture features. Therefore, the similarities in forage mass, canopy structure, and nutritional value of the pastures ensured that variations in animal performance during the experimental period were a result of the supplement used. 
Table 2. Means, standard error of mean (S.E.M.) and probability values by the $\mathrm{F}$ test of variance analysis

\begin{tabular}{|c|c|c|c|c|c|}
\hline \multirow{2}{*}{ Variables } & \multirow{2}{*}{ Mean } & \multirow{2}{*}{ S.E.M. } & \multicolumn{3}{|c|}{ Fixed effects } \\
\hline & & & Supplement & Month & Supplement * Month \\
\hline $\operatorname{FAR}^{1}$ (kg ha ${ }^{-1}$ day $)$ & 5.13 & 3.7 & 0.3243 & 0.0001 & 0.8427 \\
\hline Canopy height $(\mathrm{cm})$ & 42.9 & 0.6 & 0.2256 & 0.0012 & 0.6104 \\
\hline Forage mass $\left(\mathrm{kg} \mathrm{ha}^{-1}\right)$ & 3866 & 78 & 0.8184 & 0.0001 & 0.6315 \\
\hline Forage allowance $^{2}$ & 16.4 & 0.9 & 0.1820 & 0.0130 & 0.2716 \\
\hline Leaf $(\%)$ & 22.5 & 1.15 & 0.0749 & 0.0001 & 0.9796 \\
\hline Stem $(\%)$ & 13.3 & 0.89 & 0.1211 & 0.0001 & 0.1511 \\
\hline Dead material (\%) & 65.2 & 1.21 & 0.4910 & 0.0001 & 0.4050 \\
\hline $\mathrm{CP}^{3}$ of leaves $(\%)$ & 11.1 & 0.31 & 0.1355 & 0.0001 & 0.6164 \\
\hline IVOMD $^{4}$ of leaves $(\%)$ & 59.3 & 0.63 & 0.8719 & 0.0001 & 0.8381 \\
\hline $\mathrm{NDF}^{5}$ of leaves $(\%)$ & 75.3 & 0.18 & 0.4309 & 0.0001 & 0.3043 \\
\hline $\mathrm{ADL}^{6}$ of leaves $(\%)$ & 3.6 & 0.09 & 0.5330 & 0.0020 & 0.4006 \\
\hline CP of stems (\%) & 5.0 & 0.14 & 0.5358 & 0.0001 & 0.8681 \\
\hline IVOMD of stems (\%) & 51.2 & 0.39 & 0.9573 & 0.0001 & 0.5242 \\
\hline NDF of stems (\%) & 77.5 & 0.19 & 0.7112 & 0.0001 & 0.7625 \\
\hline ADL of stems $(\%)$ & 4.9 & 0.08 & 0.5207 & 0.0001 & 0.7483 \\
\hline
\end{tabular}

Note. ${ }^{1}$ FAR $=$ forage accumulation rate $;{ }^{2}$ Forage allowance $=\mathrm{kg}$ of dry matter per $100 \mathrm{~kg}$ liveweight $;{ }^{3} \mathrm{CP}=$ crude protein; ${ }^{4}$ IVOMD $=$ in vitro organic matter digestibility; ${ }^{5} \mathrm{NDF}=$ neutral detergente fiber; ${ }^{6} \mathrm{ADL}=$ acid detergente lignina.

\subsection{Supplement Effects}

The average daily gain (ADG) and consequently the bodyweight gain (BWG) was greater for cattle fed supplement than for cattle fed no supplement (NS), and greater for protein-energy supplement (PES) than for protein supplement (PS; Table 3). As the number of animals remained the same throughout the dry period, the observed differences in bodyweight gain per area were consequence of average daily gain (Table 3).

Based on those results, it can be suggested that the forage mass remaining from the previous wet season, when Mombaça grass was managed with $45 \mathrm{~cm}$ post-grazing residue, was sufficient to maintain a mean stocking rate of $1.4 \mathrm{AU} \mathrm{ha}{ }^{-1}\left(\mathrm{UA}=450 \mathrm{~kg}\right.$ of bodyweight) and average daily gain of $250 \mathrm{~g}$ animal ${ }^{-1}$ during the dry season (Table 3). This corroborates the recommendation of Euclides et al. (2012), in which reduction in stocking rate showed to be a viable alternative to the use of pastures of P. maximum cultivars during the dry season.

Santana et al. (2013) observed that only adjusting the stocking rate as a function of forage mass at the beginning of the dry season made it possible to obtain an average daily gain of $530 \mathrm{~g}$ per calf, in tanzania guinea grass pastures (Panicum maximum cv. Tanzânia). The higher performance of the animals observed on Tanzânia grass relative to this experiment might be attributed to the higher IVOMD of Tanzânia guinea grass as compared with Mombaça guinea grass. These authors reported a mean value of $65.5 \%$ of IVOMD in samples simulating animal grazing. In this study, considering only the leaf fraction (Figure 2C), the average was 59.3\% IVOMD (Table 2); this amount is probably higher than in the diet selected by the animals, since LP in the canopy was very low (Figure 2A), which would hinder the selection of leaves.

During the dry period Mombaça guinea grass showed high NDF and ADL concentrations and low CP and IVOMD percentages (Table 2). Therefore, in this situation supplements are required to meet the nutrient needs of weaned calf that have high energy and protein requirements. In this context, the two supplements used were effective to supplement the nutrients from the forage, resulting in an increase in bodyweight (Table 3 ). Since that the animals experienced the same pasture conditions (Table 2), a small amount of supplemental protein (average daily $140 \mathrm{~g} \mathrm{steer}^{-1}$ of $\mathrm{CP}$ ) overcame the forage $\mathrm{CP}$ deficiency (Table 2), resulted in a $85 \%$ increase in daily gain over non-supplemented steers (Table 3). Thus, PS was effective to optimize the environment in the rumen, and consequently improving both protein nutrition and energy nutrition. This supplement has been shown to be effective after weaning by Vendramini et al. (2013) and Euclides et al. (2014).

Additionally, the higher performance of supplemented animals with protein-energy supplement resulted in approximately $70 \%$ increase in daily gain compared to those supplemented with PS (Table 3 ). This finding may be explained not only by the higher concentration of energy (Table 1), but also by the higher intake of the 
supplement in relation to PS (Table 1), which resulted in a higher overall nutrient intake by animals that received PES. Similar animal performance was recorded by Euclides et al. (2014) and Garcia et al. (2014) for weaned calves grazing palisade grass receiving similar concentrate.

Table 3. Initial and final bodyweight, average daily gain, bodyweight gain per area in P. maximum cv. Mombaça guinea grass pastures, according to supplement

\begin{tabular}{|c|c|c|c|c|c|}
\hline & \multicolumn{3}{|c|}{ Supplements } & \multirow{2}{*}{ S.E.M. } & \multirow{2}{*}{$P$} \\
\hline & None & Protein & Protein-energy & & \\
\hline Initial bodyweight (kg) & 195.4 & 194.8 & 194.6 & 4.89 & 0.9910 \\
\hline Final bodyweight (kg) & 274.9 & 241.6 & 218.7 & 6.11 & 0.0001 \\
\hline Average daily gain $\left(\mathrm{g}\right.$ animal ${ }^{-1}$ day $\left.^{-1}\right)$ & $250 \mathrm{c}$ & $460 \mathrm{~b}$ & $770 \mathrm{a}$ & 0.04 & 0.0001 \\
\hline Bodyweight gain per area $\left(\mathrm{kg} \mathrm{ha}^{-1}\right)$ & $90 \mathrm{c}$ & $165 \mathrm{~b}$ & $275 \mathrm{a}$ & 12.3 & 0.0001 \\
\hline
\end{tabular}

Note. P, significance between treatments. S.E.M., standard error of the mean.

Means followed by the same letters do not differ in Tukey's test at 5\% probability.

Based on current prices, the cost of PS and PES supplements (ingredients only) was approximately 0.31 and 1.34 US\$ per steer per day, respectively (Table 1). For PS and PES supplements, this corresponds to costs of 1.47 and 2.98 US\$ per kg of extra gain above that observed on non-supplemented steers (Table 3). The use of protein-energy supplement in the post-weaning phase increases the production costs, but it may be advantageous to reduce the age at slaughter (Euclides et al., 2014) or aging at first calf (Oliveira et al., 2015). Thus, an effective strategic supplementation program must implement the most effective and lowest cost nutritional intervention to achieve production goals.

\subsection{Month Effect}

Throughout the dry season, significant changes were observed for forage accumulation rate, with the lowest value observed in August, intermediate values in July and September, and the highest values in June and October (Table 4). A marked reduction in forage accumulation during this time of year is common in the tropics (Euclides et al., 2008; Moraes et al., 2012), mainly, because of water deficit in the soil (Figure 1). Another fact which favored the reduction of growth rates was the decrease in the minimum temperature during the winter (June to September; Figure 1A). In this context, the forage disappearance observed from July to August was the result of frost, which occurred July 29 , when the minimum temperature reached to $3.9{ }^{\circ} \mathrm{C}$. This corroborates the observation of Botrel et al. (2002) that cultivars of P. maximum are moderately resistant to frost. According to Whiteman (1980), tropical grasses are susceptible to frost; its main effects are death and senescence of leaves and stems. The increase of forage accumulation rate September (Table 4) can be explained by a temperature increase and precipitation of $106 \mathrm{~mm}$ (Figure 1), which was sufficient to restore the water level in the soil (Figure 1B).

Table 4. Forage accumulation rate (FAR), daily forage allowance ( $\mathrm{kg}$ of forage dry matter per $100 \mathrm{~kg}$ liveweight), acid detergent lignin (ADL) of leaves and stems in P. maximum cv. Mombaça guinea grass pastures throughout the dry season

\begin{tabular}{llllllll}
\hline & \multicolumn{9}{c}{ Month during the dry season } & \multirow{2}{*}{ S.E.M. } & $P$ \\
\cline { 2 - 6 } & Jun. & Jul. & Aug. & Sep. & Oct. & \\
\hline FAR (kg ha ${ }^{-1}$ day) & $15.9 \mathrm{a}$ & $6.5 \mathrm{ab}$ & $-13.5 \mathrm{c}$ & $4.4 \mathrm{~b}$ & $23.1 \mathrm{a}$ & 4.1 & 0.0006 \\
Daily forage allowance & $19.6 \mathrm{a}$ & $15.3 \mathrm{~b}$ & $15.6 \mathrm{~b}$ & $14.9 \mathrm{~b}$ & $9.9 \mathrm{c}$ & 0.9 & 0.0001 \\
ADL of leaves (\%) & $3.6 \mathrm{ab}$ & $3.8 \mathrm{a}$ & $3.9 \mathrm{a}$ & $3.5 \mathrm{ab}$ & $3.3 \mathrm{~b}$ & 0.1 & 0.0020 \\
ADL of stems (\%) & $5.0 \mathrm{ab}$ & $4.9 \mathrm{~b}$ & $5.2 \mathrm{a}$ & $4.8 \mathrm{~b}$ & $4.5 \mathrm{c}$ & 0.1 & 0.0001 \\
\hline
\end{tabular}

Note. $P$, significance between treatments. S.E.M., standard error of the mean.

Means followed by the same letters do not differ in Tukey's test at $5 \%$ probability.

Forage mass and canopy height variations were best fitted by a second-order polynomial equation (Figures $2 \mathrm{~A}$ and $2 \mathrm{~B}$ ). The forage mass and consequently the canopy height decreased at increased rate throughout the dry 
period. Since the stocking rate was fixed, decreases in daily forage allowance (DFA) were also observed (Table 4); however, even at the end of the dry season, the DFA was $10 \mathrm{~kg}$ of forage dry matter per $100 \mathrm{~kg}$ bodyweight. Hodgson (1990) suggested that daily DFA should be 10 to $12 \%$ to maximize forage consumption. This ensures that, throughout the dry season, forage mass is not a limiting factor for the intake of forage by the animals.

We also observed linear decreases in the percentages of leaf and stem, and an increase in dead material percentage, throughout the dry season (Figure 2C). Those variation in the morphological components were the result not only of the low regrowth rate (Table 4) and natural senescence of grass, which generally is accelerated by water deficit (Figure 1B), but also of forage selection by the animals, which reject dead material (Brâncio et al., 2003; Trindade et al., 2007).
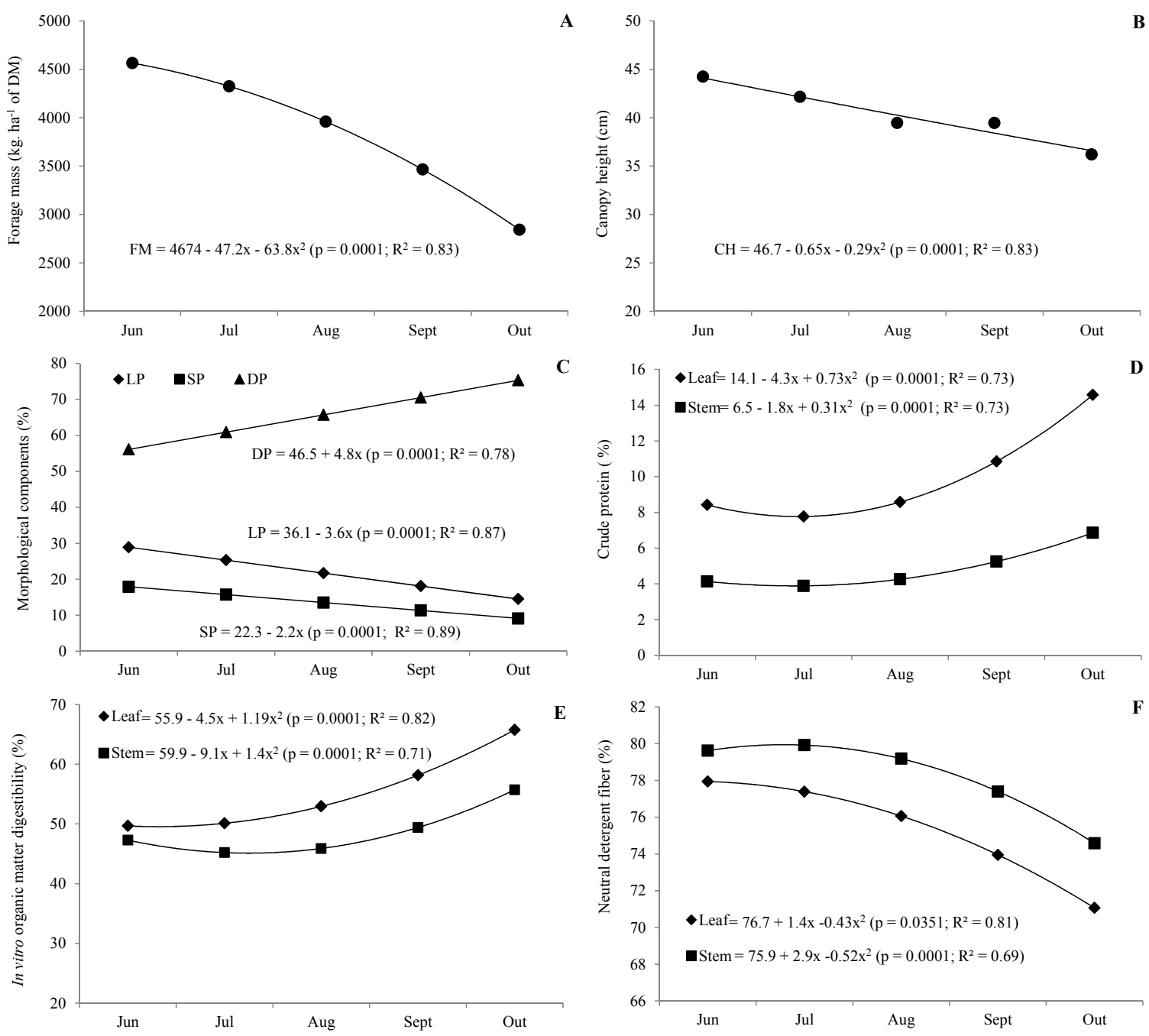

Figure 2. Herbage mass (HM) (A) canopy height (CH) (B), percentages of leaf (LP), stem (SP), and dead material (DP) (C) and percentages of crude protein (D), in vitro organic matter digestibility (E), and neutral detergent fiber (F) of Mombaça leaves and stems in Mombaça pastures throughout the dry season

Note. Leaf percentage (LP) $(\bullet)$, Stem percentage (SP) (匹), Dead material percentage (DP) (ム)

Excluding acid detergent lignin, the curve that best fit the variables associated with nutritional value was the quadratic. Decreases were observed in the percentages of crude protein and in vitro organic matter digestibility up to August, and thereafter increased (Figures 2D and 2E); the reverse was observed for neutral detergent fiber content of the leaves and stems (Figure 2F). The ADL content of the leaves and stem was highest in August, lowest in October, and intermediate in other months of the dry season (Table 4). The decrease in nutritional value 
until August was a consequence of the decrease in proportion of leaves in the sward (Figure 2C), negative effects of freezing event, and greater maturity of the plants. On the other hand, as soon as rains resumed (Figure 1) the plants began to recover, and we observed an improvement of the pasture's nutritive value (Figures 2C, 2D, and 2F).

A significant difference was also observed $(\mathrm{P}=0.0001)$ in animal performance throughout the dry season (Figure $3)$. Regardless of the supplement used, the lowest ADG was observed during the first month $\left(150 \mathrm{~g}^{\text {animal }}{ }^{-1}\right.$ day $\left.^{-1}\right)$, the highest during the second month (965 $\mathrm{g}$ animal $^{-1}$ day $\left.^{-1}\right)$, and an intermediate level in the third (425 $\mathrm{g}$ animal $^{-1}$ day $\left.^{-1}\right)$ and fourth (440 $\mathrm{g}$ animal $^{-1}$ day $\left.^{-1}\right)$ months.

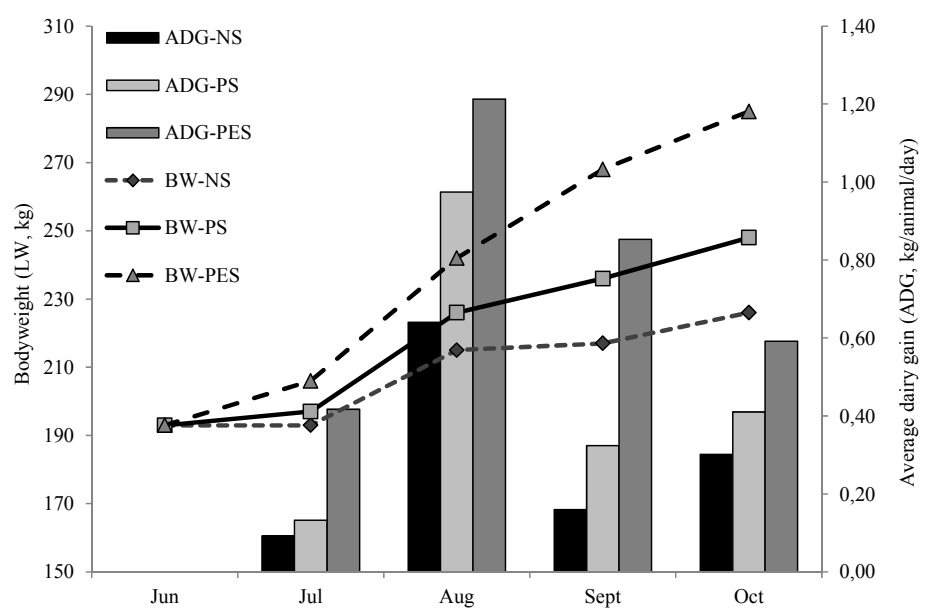

Figure 3. Average daily gains and bodyweight of animals non-supplemented (NS) and those supplemented with protein (PS) or protein-energy (PES) supplements, throughout the dry season

The lower bodyweight gain observed during the first month (Figure 3) can be attributed to post-weaning stress, since at this stage, animals generally show weight loss and greater susceptibility to diseases (Haddad \& Mendes, 2010). Furthermore, animals were infested with ticks at the beginning of the experiment, but as soon as it was applied an insecticide, the infestation decreased and the animals began to gain weight again. In addition, the high average daily gain recorded during the second month (Figure 3) can be attributed in part to compensatory gain, since we observed the lowest forage nutritional value (Figures 2D, 2E, and 2F) during this period.

The improvement of the pasture's nutritive value beginning in September (Figures 2D, 2E, and 2F) has not reflected in the bodyweight gain of the non-supplemented steers in the second half of the dry season, being in average $230 \mathrm{~g} \mathrm{animal}^{-1}$ day $^{-1}$ (Figure 3). This fact could be explained by the decrease in LP and the increase in MP (Figure 2C), possibly hindering the selection of leaves by the animals. According to Brâncio et al. (2003) and Difante et al. (2009), the presence of dead material in the sward could act as physical barrier by interfering to accessibility and ease of the leaf harvest, resulting in a decrease in forage intake, and consequently a lower average daily gain is expected. On the other hand, steers receiving protein-energy supplement gained nearly 500 $\mathrm{g} \mathrm{day}^{-1}$ more than those non-supplemented (Figure 3). Thus, it is probable that the amount of supplement intake, approximately, $2 \mathrm{~kg}$ animal ${ }^{-1}$ day $^{-1}$ (supplied $1500 \mathrm{~g}$ of TDN and $480 \mathrm{~g}$ of CP) played an important role in daily nutrient intake. It is highlighted that protein is typically considered the primary limiting nutrient, during the dry period; however, increasing feed intake with protein supplements did not result in adequate increases in energy intake to achieve a higher rate of gain $\left(>700 \mathrm{~g} \mathrm{steer}^{-1}\right.$ day $\left.^{-1}\right)$.

Supplemental feeding to balance the nutrients in the diet of grazing animals could be an important tool in a nutritional strategy to increase productivity in grazing systems. If the target is the reduction of the slaughter age, the supplementation of weaned calves is essential. In this context, Euclides et al. (2014) observed that the use of supplementation with protein or protein-energy soon after weaning was essential to reduce slaughter ages to 22 and 24 months, respectively. However, economic considerations can be crucial for the decision-making process with regard to the employment of this technology. For this reason, alternatives have been sought to minimize production costs without compromising production levels. 


\section{Conclusions}

Mombaça guinea grass pastures with $45 \mathrm{~cm}$ height at the end of the wet season have enough forage mass for maintenance throughout the dry season about $1.4 \mathrm{AU} \mathrm{ha}^{-1}$, and reasonable nutritive value to provide small gains.

Considering the nutritive value of Mombaça guinea grass during the dry period, protein and energy supplementation is required for weaned calves to optimize their performance.

\section{References}

Allen, V. G., Batello, C., Berretta, E. J., Hodgson, J., Kothmann, M., Li, X., ... The Forage and Grazing Terminology Committee. (2011). An international terminology for grazing lands and grazing animals. Grass and Forage Science, 66, 2-28. https://doi.org/10.1111/j.1365-2494.2010.00780.x

Barioni, L. G. (2011). Embrapa Invernada 1.0. Retrieved February 10, 2014, from http://www.invernada.cnptia. embrapa.br

Botrel, M. A., Alvim, M. J., Ferreira, R. P., \& Xavier, D. F. (2002). Forage potential of grass species under conditions of low temperature and high altitude. Pesquisa Agropecuária Brasileira, 37(3), 393-398. https://doi.org/10.1590/S0100-204X2002000300021

Brâncio, P. A., Euclides, V. P. B., Nascimento Júnior, D., Fonseca, D. M., Almeida, R. G., Macedo, M. C. M., \& Barbosa, R. A. (2003). Evaluation of three cultivars of Panicum maximum Jacq. under grazing: forage availability, post grazed stubble height and participation of leaves, stems, and dead material. Revista Brasileira de Zootecnia, 32(1), 55-63. https://doi.org/10.1590/S1516-35982003000100007

Difante, G. S., Euclides, V. P. B., Nascimento Júnior, D., Da Silva, S. C., Torres Júnior, R. A. A., \& Sarmento, D. O. L. (2009). Ingestive behaviour, herbage intake and grazing efficiency of beef cattle steers on Tanzania guineagrass subjected to rotational stocking managements. Revista Brasileira de Zootecnia, 38(6), 1001-1008. https://doi.org/10.1590/S1516-35982009000600005

Euclides, V. P. B, Euclides Filho, K., Montagner, D. B., Figueiredo, G. R., \& Lopes, F. C. (2014). Alternatives for intensification of beef production under grazing. Tropical Grasslands-Forrajes Tropicales, 2(1), 48-50. https://doi.org/10.17138/TGFT(2)48-50

Euclides, V. P. B., \& Medeiros, S. R. (2005). Suplementação alimentar de bovinos em pastagens. In L. M. Carvalho, R. Zoccal, P. C. Martins, P. B. Arcuri, \& M. S. P. Moreira (Eds.), Tecnologia e gestão na atividade leiteira (pp. 203-240). Embrapa Gado de Leite, Juiz de Fora, Brazil.

Euclides, V. P. B., Macedo, M. C. M., Valle, C. B., Difante, G. S., Barbosa, R. A., \& Cacere, E. R. (2009). Forage nutritive value and animal production in Brachiaria brizantha pastures. Pesquisa Agropecuária Brasileira, 44(1), 98-106. https://doi.org/10.1590/S0100-204X2009000100014

Euclides, V. P. B., Macedo, M. C. M., Zimmer, A. H., Jank, L., \& Oliveira, M. P. (2008). Evaluation of Panicum maximum cvs Mombaça and Massai under grazing. Revista Brasileira de Zootecnia, 37(1), 18-26. https://doi.org/10.1590/S1516-35982008000100003

Euclides, V. P. B., Montagner, D. B., Araújo, A. R., \& Barbosa, R. A. (2012). Cultivares de Panicum maximum para a produção de ruminantes. Simpósio sobre Manejo Estratégico da Pastagem (pp. 129-152). Universidade Federal de Viçosa, Viçosa, Brazil.

Garcia, J., Euclides, V. P. B., Alcalde, C. R., Difante, G. S., Medeiros, S. R. (2014). Consumo, tempo de pastejo e desempenho de novilhos suplementados em pastos de Brachiaria decumbens, durante o período seco. Semina: Ciências Agrárias, 35(4), 2095-2106. https://doi.org/10.5433/1679-0359.2014v35n4p2095

Haddad, C. M., \& Mendes, C. Q. (2010). Manejo da estação de monta, das vacas e das crias. In A.V. Pires (Ed.), Bovinocultura de Corte (pp. 129-142). FEALQ, Piracicaba, Brazil.

Hodgson, J. (1990). Grazing management: science into practice. Longman Scientific and Technical, Harlow, UK.

Marten, G. C., Shenk, J. S., \& Barton, F. E. (1989). Near infrared reflectance spectroscopy (NIRS), analysis of forage quality. ARS, Washington, USA.

Moraes, E. H. B. K., Paulino, M. F., Zervoudaskis, J. T., Detmann, E., Valadares Filho, S. C., \& Moraes, K. A. K. (2012). Productive and economic aspects of crossbreed steers fed protein-energy supplements with urea. Revista Brasileira de Zootecnia, 41(5), 1278-1284. https://doi.org/10.1590/S1516-35982012000500027 
Morais, J. A. S., Queiroz, M. F. S., Keli, A., Veja, A., Fiorentini, G., Canesin, R. C., Reis, R. A., \& Berchielli, T. T. (2014). Effect of supplementation frequency on intake, behavior and performance in beef steers grazing Marandu grass. Animal Feed Science and Technology, 189(3), 63-71. https://doi.org/10.1016/j.anifeedsci. 2014.01.005

National Research Council (NRC). (1996). Nutrient requirements of beef cattle (7th ed., p. 242). Washington DC.: Academic Press.

Oliveira, A. P., Casagrande, D. R., Bertipaglia, L. M. A., Barbero, R. P., Berchielli, T. T., Ruggieri, A. C., \& Reis, R. A. (2015). Supplementation for beef cattle on Marandu grass pastures with different herbage allowances. Animal Production Science, 56(1), 123-129. https://doi.org/10.1071/AN14636

Santana, M. C. A., Euclides, V. B. P., Mancio, A. B., Medeiros, S. R., Costa, J. A. R., \& Oliveira, R. L. (2013). Intake and performance of yearling steers grazing guineagrass (Panicum maximum cv. Tanzânia) pasture supplemented with different energy sources. Asian Australasian Journal of Animal Sciences, 26, $349-357$. https://doi.org/10.5713/ajas.2012.12226

SAS Institute Inc. (2013). SAS/STAT ${ }^{\circledR} 12.3$ User's Guide. Cary, NC: SAS Institute Inc.

Silva, F. F., Sá, J. F., Schio, A. R., Ítavo, L. C. V., Silva, R. R., \& Mateus, R. G. (2009). Grazing supplementation: Availability and quality x supplementation levels x performance. Revista Brasileira de Zootecnia, 38, 371-389. https://doi.org/10.1590/S1516-35982009001300037

Trindade, J. K., Da Silva, S. C., Souza Júnior, S. J., Giacomini, A. A., Zeferino, C. V., Guarda, V. D., \& Carvalho, P. C. F. (2007). Morphological composition of the herbage consumed by beef cattle during the grazing down process of marandu palisadegrass subjected to rotational strategies. Pesquisa Agropecuaria Brasileira, 42, 883-890. https://doi.org/10.1590/S0100-204X2007000600016

Vendramini, J. M. B., Arthington, J. D., \& Sollenberger, L. E. (2013). Effects of Increasing Rumen-Undegradable Protein Supplementation Levels on Early Weaned Calves Grazing Stargrass. Crop Science, 53, 322-328. https://doi.org/10.2135/cropsci2012.06.0340

Whiteman, P. C. (1980). Tropical Pasture Science. Oxford University Press, New York, USA.

\section{Copyrights}

Copyright for this article is retained by the author(s), with first publication rights granted to the journal.

This is an open-access article distributed under the terms and conditions of the Creative Commons Attribution license (http://creativecommons.org/licenses/by/4.0/). 